\title{
POLSKIE ELIMINACJE DO MIĘDZYNARODOWEGO KONKURSU STATYSTYCZNEGO (ANG. THE INTERNATIONAL STATISTICAL LITERACY PROJECT, ISLP)
}

\author{
Pewnego dnia myślenie statystyczne stanie się tak niezbędne, jak umiejętność czyta- \\ nia i pisania \\ H. G. Wells (1866-1946)
}

Rok 2013 to Międzynarodowy Rok Statystyki, w którym biorą udział różne organizacje działające na rzecz statystyki. Inicjatorami akcji są: Międzynarodowy Instytut Statystyczny, Międzynarodowe Towarzystwo Biometryczne, Instytut Statystyki Matematycznej, Amerykańskie Towarzystwo Statystyczne oraz Królewskie Towarzystwo Statystyczne Wielkiej Brytanii. Międzynarodowy Konkurs Statystyczny (ang. The International Statistical Literacy Project, ISLP) to konkurs, który od ponad 10 lat jest organizowany na całym świecie przez Międzynarodowy Instytut Statystyczny (ang. International Statistical Institute, ISI). Celem konkursu jest promocja i popularyzacja umiejętności statystycznych na całym świecie wśród młodzieży szkół gimnazjalnych i ponadgimnazjalnych. Aby wziąć udziału w konkursie, należy przesłać plakat naukowy prezentujący własne wyniki badań.

23 czerwca 2013 roku na Wydziale Ekonomii i Zarządzania Uniwersytetu w Białymstoku odbyła się uroczysta gala finałowa pierwszych, krajowych eliminacji do Międzynarodowego Konkursu Statystycznego. Celem tegorocznego konkursu było rozwijanie kompetencji statystycznych młodzieży z uwzględnieniem problematyki rolnictwa i otaczającego nas środowiska. Konkurs cieszył się bardzo dużym zainteresowaniem, stronę internetową konkursu [www.islp.pl] odwiedziło ponad 3,5 tys. osób. W eliminacjach krajowych wzięło udział 115 uczniów z całej Polski. W kategorii szkół gimnazjalnych zgłoszono 16 prac, zaś w kategorii szkół ponadgimnazjalnych - 25 prac.

Jury, pod przewodnictwem dr hab. Ewy Roszkowskiej, prof. UwB, wyłoniło zwycięzców konkursu oraz przyznało kilka wyróżnień. W kategorii szkół gimnazjalnych zwyciężył poster przygotowany przez uczniów z Białegostoku: Bartłomieja Kosińskiego i Wiktora Krukowskiego pt.: Czy nawozy sztuczne wpływają na wzrost roślin i na ilość plonów?. W kategorii szkół ponadgimnazjalnych wygrał poster przygotowany przez uczniów ze Słupska: Monikę Leończyk i Nicolę Leończyk pt.: Wpływ turbin wiatrowych na organizmy żywe we wsi Sierakowo. Prace zwycięzców wzięły udział w finale International Statistical Literacy Project, który odbył się w dniach 25-30 sierpnia 2013 r. podczas Światowego Kongresu Statystyki w Hongkongu. Dodatkowo, Uniwersytet w Białymstoku, Wydział Ekonomii i Zarządzania oraz Politechnika Białostocka dla laureatów I miejsca szkół ponadgimnazjalnych ufundowały indeksy.

Wszystkie wyróżnione osoby otrzymały nagrody rzeczowe, ufundowane przez współorganizatorów konkursu, tj.: Dziekana Wydziału Ekonomii i Zarządzania Uniwersytetu w Białymstoku, Politechnikę Białostocką, Urząd Marszałkowski Województwa Podlaskiego, Urząd Miejski w Białymstoku, StatSoft sp. z. o.o. z Krakowa, Urząd Statystyczny w Białymstoku oraz Kuratorium Oświaty w Białymstoku. Konkurs został objęty Patronatem Honorowym przez Woje-

\footnotetext{
${ }^{1}$ Krajowy Koordynator Międzynarodowego Konkursu Statystycznego (The International Statistical Literacy Project).
} 
wodę Podlaskiego, Marszałka Województwa Podlaskiego oraz Prezydenta Miasta Białegostoku. Organizacji przedsięwzięcia podjęli się: Departament Edukacji Urzędu Miejskiego w Białymstoku, Miejski Ośrodek Doradztwa Metodycznego w Białymstoku oraz XI Liceum Ogólnokształcące im. Rotmistrza Witolda Pileckiego w Białymstoku. W przygotowanie konkursu były zaangażowane następujące osoby: Katarzyna Łogwiniuk - Krajowy Koordynator Konkursu - XI Liceum Ogólnokształcące im. Rotmistrza Witolda Pileckiego w Białymstoku, Izabela Popławska - Miejski Ośrodek Doradztwa Metodycznego oraz Halina Wasiak - Radna Rady Miasta Białystok.

I miejsce w kategorii szkół gimnazjalnych: Bartłomiej Kosiński, Wiktor Krukowski, Czy nawozy sztuczne wpływają na wzrost roślin i na ilość plonów?, Zespół Szkół Nr 6, Publiczne Gimnazjum Nr 12 w Białymstoku; nauczyciel: Barbara Dębska.

\section{Czy nawozy sztuczne wpływają na wzrost roślin i na ilość plonów?}

Nawozy sztuczne sa to sole mineralne lub inne zwiazki chemiczne dodawane do gleby w celu wyrównania ubytków pewnych pierwiastków, składające się z azotu, fosforu, wapnia, potasu. Rozróżnia się nawozy jednoskładnikowe, zawierajace tylko jeden związek chemiczny i wieloskładnikowe, które są mieszaniną kilku związków prostych lub jednym związkiem chemicznym zawierającym kilka pierwiastków przyswajalnych przez rośline.

Aby utrzymać żyzność gleby należy jej zwracać substancje przyswajalne, $i$ te pobrane przez rośliny $i$ te zebrane $z$ plonem. Wysokość plonów zależy od tego pierwiastka, który znajduje się w glebie $w$ ilości minimalnej w stosunku do potrzeb rośliny.

\section{Materiały:}

* 3 takie same roślinki (paprotki),

* Preparat do podlewania paprotek (NPK),

* Jednorazowe paski do mierzenia $\mathrm{pH}$

(Merck)

Metody :

Podlewanie roślinki A sama woda.

Podlewanie roślinki B preparatem do paprotek (zgodnie z zaleceniami producenta).

Podlewanie roślinki $\mathrm{C}$ preparatem o 3 razy mocniejszym działaniu (przedawkowanie)
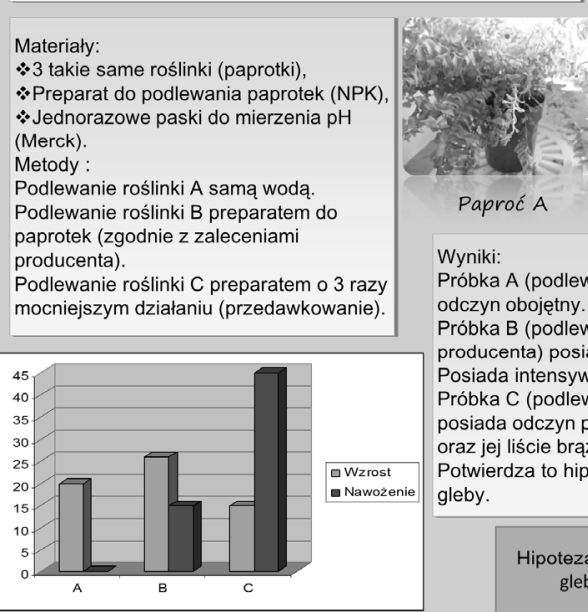

Celem pracy jest:

1. Zbadanie, czy przedawkowanie nawozów sztucznych ma niekorzystny wpływ na wzros roślin.

2. Analiza statystyczna, jak nawozy azotowe wpływaja na ilość plonów.

Obserwacja:

Rośliny nawożone nawozami sztucznymi nie zawsze lepiej rosna.

Problem badawczy:

Co sprawia, że jakość roślin nawożonych

nawozami sztucznymi czasami spada?

Hipoteza: Nawozy sztuczne zmieniają pH gleby, co czasami pogarsza jakość wzrostu roślin.
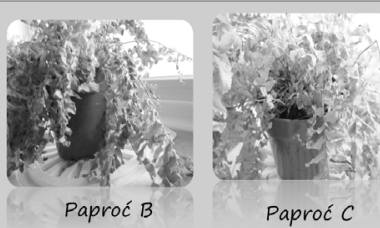

Wyniki:

Próbka A (podlewana zwykła woda) posiada odczyn pH-7, czyli odczyn obojętny.

Próbka B (podlewana nawozem zgodnie z zaleceniami producenta) posiada odczyn pl l-6, czyli odczyn kwasowy. Posiada intensywniejsza zielona barwe oraz szybciej wzrasta Próbka C (podlewana roztworem $3 x$ silniej skoncentrowanym) posiada odczyn pH-8, czyli odczyn zasadowy. Rośnie wolniej oraz jej liście brazowieja.

Potwierdza to hipoteze, że nawozy sztuczne wpływają na odczyn gleby

Hipoteza potwierdzona. Nawozy sztuczne zmieniają pH gleby, a ich nadmiar jest szkodliwy dla roślin

Korzystając z badań przeprowadzonych w Stacjach Doświadczalnych Instytutu Uprawy Nawożenia i Gleboznawstwa Puławach można przedstawić zależność wzrostu plonów zbóż ( $w \mathrm{~kg} \mathrm{z}$ ha) od nawożenia azotem ( $\mathrm{N} \mathrm{kg/ha).} \mathrm{Na}$ początku obserwujemy wzrost plonów, a później spadek.

Zależność ta jest zbieżna z wynikami naszego doświadczenia.

\begin{tabular}{|c|c|c|c|}
\hline \multicolumn{4}{|c|}{ Zboża ozime } \\
\hline $\begin{array}{c}\text { Dawka N } \\
\text { kg/ha }\end{array}$ & $\begin{array}{c}\text { Pszenica } \\
\text { Kg z ha }\end{array}$ & $\begin{array}{c}\text { Pszenżyto } \\
\text { Kg z ha }\end{array}$ & $\begin{array}{c}\text { Żyto } \\
\text { Kg z ha }\end{array}$ \\
\hline 0 & 3960 & 2955 & 2685 \\
\hline 43 & 5140 & 4487 & 3883 \\
\hline 86 & 5659 & 5105 & 4464 \\
\hline 129 & 5694 & 5480 & 4825 \\
\hline 172 & 7597 & 5637 & 4955 \\
\hline 215 & 5595 & 5473 & 5003 \\
\hline
\end{tabular}

Wzrost plonów zbóż ozimych względem nawożenia

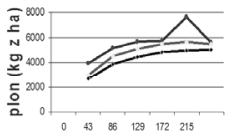

-Pszenic --Pszenżyto --Żyto nawożenie (kg/ha) 
I miejsce w kategorii szkół ponadgimnazjalnych: Monika Leończyk, Nicola Leończyk, Wpływ turbin wiatrowych na organizmy żywe we wsi Sierakowo, II Liceum Ogólnokształcące z Oddziałami Dwujęzycznymi im. A. Mickiewicza w Słupsku; nauczyciele: Grażyna i Jarosław Linder.

\title{
WPKYW TURBIN WIATROWYCH NA ORGANIZMY ZOMWE WE WSI SIERAKOWO
}

\begin{abstract}
Wykorzystanie energii pozyskiwanej ze źródeł odnawialnych staje się na całym świecie coraz bardziej powszechne. Nagły wzrost liczby budowanych farm wiatrowych budzi jednak pewien sprzeciw, głównie ze strony mieszkańców terenów, na których turbiny mają być zainstalowane. W pracy postanowiłyśmy sprawdzić powagę tych obaw. $W$ tym celu przez kilka lat prowadziłyśmy pracę badawczą związaną z wpływem turbin wiatrowych na organizmy żywe. Do celów badawczych wybrałyśmy farmę wiatrową we wsi Sierakowo w Gminie Kobylnica koło Słupska.
\end{abstract}

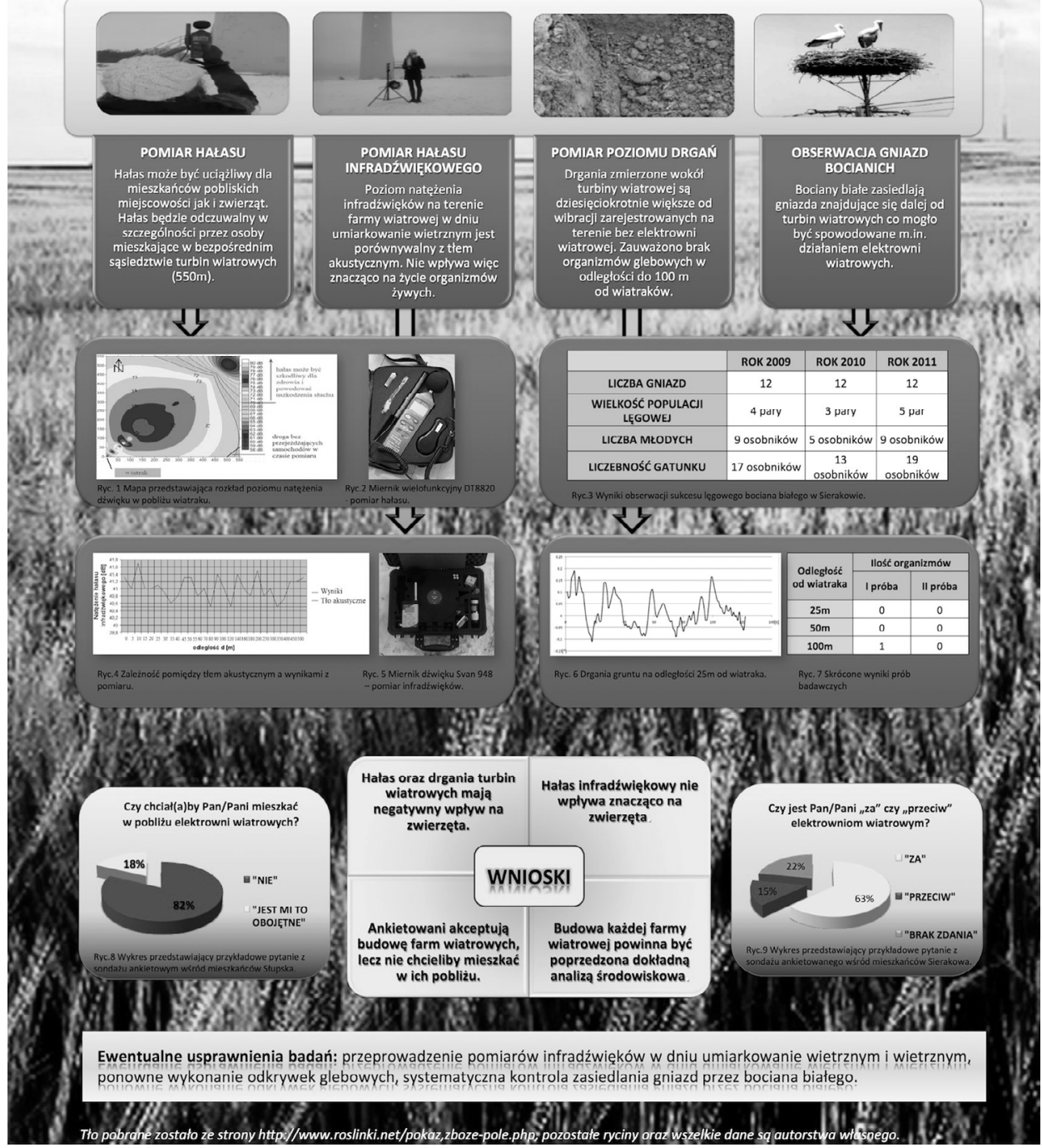

